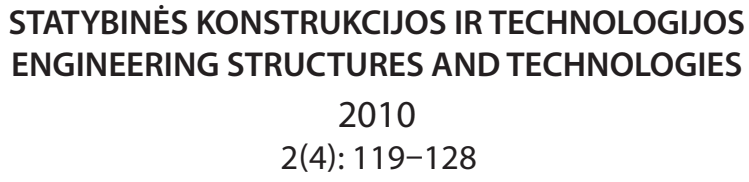

\title{
VARIABILITY OF CHARRING ALONG THE WOODEN WALL STUDS
}

\author{
Alar Just ${ }^{1}$, Tarmo Tera ${ }^{2}$ \\ Tallinn University of Technology, Ehitajate tee 5, Tallinn, Estonia \\ E-mails: 1'ajust@staff.ttu.ee; ${ }^{2}$ tarmo.tera@astlanda.ee
}

Received 2308 2010; accepted 6102010

\begin{abstract}
The effect of timber densities on the charring of timber members insulated by heat-resistant mineral wool is described in this paper. Special attention is given to variability of charring along the stud. After the fire tests, the studs were saved in their entire length. Char layer was mechanically removed from the studs under investigation. Charred studs of timber frame walls were scanned three-dimensionally over the full length after full-scale fire tests. Densities were measured by X-ray and optical vibration scanner. Cross-section properties and densities of the studs were measured along the stud. Charring rate is not uniform along the full length of a single timber wall stud. This corresponds probably to the variation of density of wood. Adjusting the design model for charring of timber frame assemblies, as given in EN 1995-1-2, to allow for the influence of density may give an advantage for members with higher density.
\end{abstract}

Keywords: The Charring rate, timber-frame assemblies, variability of charring, effect of density.

\section{Symbols}

$b \quad$ cross-section width;

$d_{\text {char }}$ charring depth;

$d_{\text {char, }}$ notional charring depth;

$k_{\mathrm{p}} \quad$ protection factor;

$k_{\mathrm{s}} \quad$ cross-section factor;

$k_{\mathrm{n}} \quad$ factor to convert irregular charring depth into a notional charring depth;

$k_{\text {dens }}$ factor to take effect of density into account;

$t$ time from the start of fire;

$t_{\mathrm{ch}} \quad$ start time of charring;

$t_{\mathrm{f}} \quad$ failure time of cladding;

$W$ section modulus;

\section{Introduction}

Typical timber-frame assemblies consist of timber wall studs or floor joists and claddings, see Figure 1. The cavities between timber elements may be void or filled with insulation. Cladding on the fire-exposed side is the first and the most important barrier. When analysing the fire design of timber studs, the reduction of cross-section by charring depth is the most important design consideration.
$W_{\mathrm{f}} \quad$ section modulus of the residual cross-section;

$\beta \quad$ charring rate;

$\beta_{0}$ one-dimensional basic design charring rate;

$\beta_{\mathrm{n}} \quad$ notional charring rate;

$\rho$ density. 
important role in protecting the sides of timber members. If the insulation is heat-resistant and remains in place, the stud is more or less protected on the wide sides of the cross-section. However, if the insulation is not heat-resistant, or if the cavities are void, then there is rapid surface recession when exposed to fire. Charring takes place on both the narrow and the wide sides.

Failure of cladding does not occur simultaneously at different positions. For this research, cladding was not used, as we wanted to eliminate the uncertainty introduced by the fall-off of cladding.

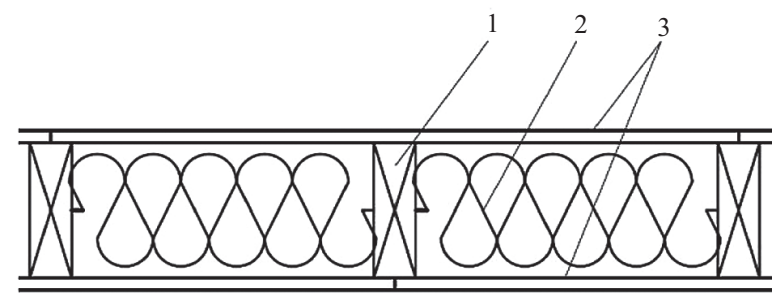

KEY: 1 - timber member, 2 - insulation, 3 - cladding

Fig. 1. Typical timber frame assembly

For softwood with densities above $290 \mathrm{~kg} / \mathrm{m}^{3}$, the charring rate values in EN 1995-1-2 are independent of density. For hardwoods, the charring rate varies linearly for densities between 290 and $450 \mathrm{~kg} / \mathrm{m}^{3}$.

Babrauskas (2005) has compared works of different authors and concludes that if the density of solid wood is in the range of $400-550 \mathrm{~kg} / \mathrm{m}^{3}$, then the charring rate under fire-resistance test furnace conditions will be in the range of $0,5-0,8 \mathrm{~mm} / \mathrm{min}$. Cachim and Franssen (2010) show the numerical analysis based on the conductive model of EN 1995-1-2. They found a good agreement of charring rate values of EN 1995-1-2 with the conductive model for densities around $450 \mathrm{~kg} / \mathrm{m}^{3}$.

Friquin (2010) compares different factors affecting the charring rate. The change of charring rate as a result of changing one property or factor varies greatly. The difference in charring rate between different softwood species is about 12 to $28 \%$. Schaffer (1967) found an obvious relationship between the dry specific density and the charring rate of wood, where the charring rate decreases with increasing density. A study by White (1988), with Engelmann spruce with 10\% moisture content, shows a $22 \%$ difference in charring rate for a change in density from $343 \mathrm{~kg} / \mathrm{m}^{3}$ to $425 \mathrm{~kg} / \mathrm{m}^{3}$.

Syme (1994) found an effect of wood density on the charring depth in Australian tests with fire similar to ISO 834 fire. This effect covered only specimens with density 500 to $900 \mathrm{~kg} / \mathrm{m}^{3}$.
Australian fire design rules for timber structures AS 1720.4 consist of rules for calculating notional charring rate dependent on density:

$C=0,4+(280 / D)^{2}$

where $C$ - notional charring rate $(\mathrm{mm} / \mathrm{min}) ; D$ - wood density with moisture content $12 \%\left(\mathrm{~kg} / \mathrm{m}^{3}\right)$.

The aim of this article is to study the effect of variability of charring along the members of wooden floor and wall assemblies insulated with heat-resistant mineral wools, such as stone wool and heat-resistant glass wool, and to detect the possible influence of density of wood on the charring rate. Heat-resistant glass wool is a new innovative glass wool with high maximum service temperature.

\section{Charring rate according to EN 1995-1-2}

Rules for fire design of wall and floor assemblies insulated by stone wool and glass wool are given in Annex C of EN 1995-1-2.

Charring is the most important parameter in the design of timber-frame members for fire resistance. Unprotected members start to char immediately when exposed to fire. For protected members, charring does not occur until $300{ }^{\circ} \mathrm{C}$ has been reached behind the protection, at which temperature slow charring starts and continues until failure of the protection, after which fast charring starts, see Figure 2. In general, for the design of fire resistance of a timber member the original cross-section must be reduced by the charring depth. Annex C of EN 1995-1-2 gives a charring model for small timber members of wall and floor assemblies insulated by mineral wool. This model, created by König et al. (2000), should be used for calculation of the fire resistance of lightweight timber structures. It covers the protected phase for glass wool and stone wool, and the post-protection phase for stone wool as long as the insulation stays in place.

Timber members are protected by insulation on their wide sides. Charring takes place mainly on the fire-exposed narrow side. Due to the heat flux through the insulation, the timber members also char on their wide sides, giving rise to extensive arris roundings, see Figure 3. For simplicity, the irregular residual crosssection is replaced by an equivalent rectangular crosssection, replacing the charring depth $d_{\text {char }}$ and arris roundings with the notional (or equivalent) charring depth $d_{\text {char, n }}$.

Notional charring depth is regarded as

$d_{\text {char, } \mathrm{n}}=\beta_{\mathrm{n}} t$. 
The notional charring rate of small sized timber frame members is given as

$\beta_{\mathrm{n}}=k_{\mathrm{p}} k_{\mathrm{s}} k_{\mathrm{n}} \beta_{0}$,

where $\beta_{0}$ is the one-dimensional charring rate for timber, given as

$\beta_{0}=0,65 \frac{\mathrm{mm}}{\mathrm{min}}$.

Coefficients $k_{\mathrm{p}}, k_{\mathrm{s}}$ and $k_{\mathrm{n}}$ are explained as follows:

The protection factor $k_{\mathrm{p}}$ takes the influence of protective cladding on charring into account. In this research no cladding was used, in order to exclude its influence on protection. For unprotected members, $k_{\mathrm{p}}=1$.

The cross-section factor $k_{\mathrm{s}}$ takes the width of the cross-section into account. Charring is faster when the cross-section is smaller, due to two-dimensional heat

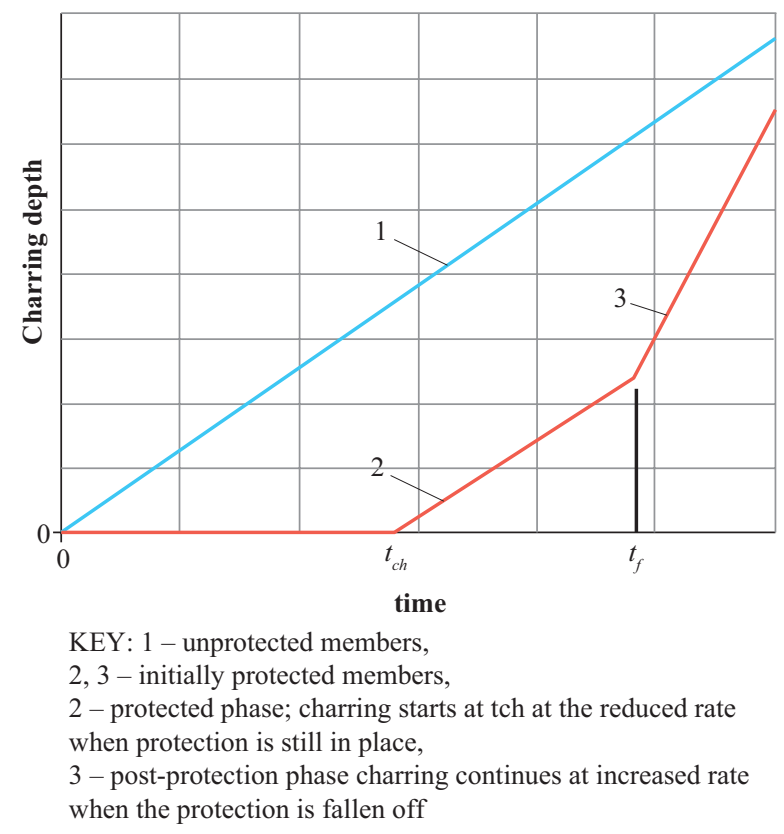

Fig. 2. Charring of timber studs with and without protection
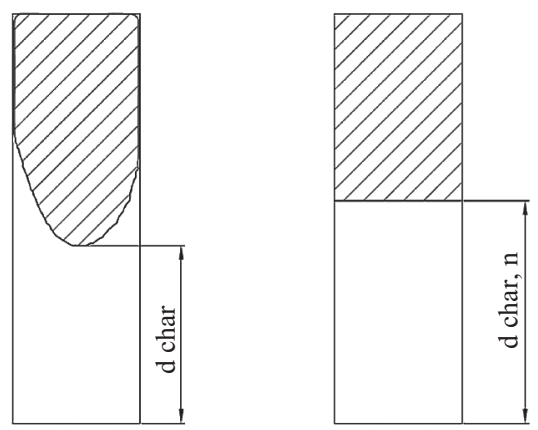

Fig. 3. Description of charring depths of cross-section flux within the member. By König (2000) it is given as Equation (5), while EN 1995-1-2 gives only a table with values for specific widths $b$. New results from Just (2009) and Schmid (2010) lead to increased cross-section factor, as given by Equation (6).

$$
\begin{aligned}
& k_{\mathrm{s}}= \\
& \left\{\begin{array}{cc}
0,000167 b^{2}-0,029 b+2,27 & 38 \mathrm{~mm} \leq b \leq 90 \mathrm{~mm}, \\
1 & b>90 \mathrm{~mm}
\end{array}\right. \\
& k_{\mathrm{s}}= \\
& \left\{\begin{array}{cc}
0,00023 b^{2}-0,045 b+3,19 & 38 \mathrm{~mm} \leq b \leq 90 \mathrm{~mm} . \\
1 & b>90 \mathrm{~mm}
\end{array}\right.
\end{aligned}
$$

In this study, Equation (6) is used for determining factor $k_{\mathrm{s}}$. For studs with cross-section width of $45 \mathrm{~mm}$, the factor $k_{\mathrm{s}}=1,6$.

Coefficient $k_{\mathrm{n}}$ converts the irregular charring depth into a notional charring depth, see Figure 3. It depends on time, cross-section dimensions and crosssection properties (area, section modulus or second moment of area). The value $k_{\mathrm{n}}=1,5$ given by EN 19951-2 is a reasonable approximation for the notional charring depth, and would be relevant for a relative resistance between 40 and $20 \%$ of the initial section modulus $W(t=0)$. The value $k_{\mathrm{n}}=1,5$ is on the safe side in the cases of the charring depths of this study.

\section{Full-scale fire tests}

Series of full-scale tests were performed in order to study the post-protection behaviour of the insulations, see Just (2009). Test wall assemblies were equipped with additional thermocouples on the sides and inside timber studs, and behind the boards and insulation. Observations were noted and photos taken both of the fire-exposed side and of the unexposed side. The tests were also investigated by thermo-camera. Tests were performed over 30 - 60 minutes until $60 \mathrm{~mm}$ charring of timber was reached on the narrow side.

Full-scale tests described here were performed without cladding on the exposed side in order to reduce the influence of difficult-to-predict failure of the cladding. Test walls had two to four different insulations in each test, see Figure 4. Table 1 shows the main components of the test assemblies. Two different times are given in Table 2 for test durations. Turn-off of the fire indicates the time when heating in the test furnace was stopped. Wooden elements continued to burn 
Table 1. Test register

\begin{tabular}{|c|c|c|c|c|c|c|}
\hline $\begin{array}{c}\text { Test } \\
\text { no. }\end{array}$ & Test date & $\begin{array}{c}\text { Exposed } \\
\text { side }\end{array}$ & Stud & $\begin{array}{c}\text { Insu- } \\
\text { lation 1 }\end{array}$ & $\begin{array}{c}\text { Insu- } \\
\text { lation 2 }\end{array}$ & $\begin{array}{c}\text { Unex- } \\
\text { posed } \\
\text { side }\end{array}$ \\
\hline 2.2 & 28.1 .2009 & - & $45 \times 145$ & $\begin{array}{c}\text { RW1 } \\
\text { RW3 }\end{array}$ & $\begin{array}{c}\text { RW2 } \\
\text { RW4 }\end{array}$ & $2 \mathrm{GtA}$ \\
\hline 2.3 & 29.1 .2009 & - & $45 \times 145$ & GWF2 & GWF1 & 2GtA \\
\hline 2.4 & 11.2 .2009 & - & $45 \times 145$ & GWF2 & RW4 & 2GtA \\
\hline
\end{tabular}

Table 2. Test durations

\begin{tabular}{|c|c|c|}
\hline Test no. & $\begin{array}{c}\text { Turn off } \\
\text { of fire }\end{array}$ & Extinguishing \\
\hline 2.2 & $58 \mathrm{~min}$ & $63 \mathrm{~min}$ \\
\hline 2.3 & $58 \mathrm{~min}$ & $62 \mathrm{~min}$ \\
\hline 2.4 & $55 \mathrm{~min}$ & $58 \mathrm{~min}$ \\
\hline
\end{tabular}

until the test wall was removed from the furnace and extinguished. Time from turn-off of fire to complete extinguishing was 3-5 minutes.

Only test walls without cladding were investigated in this study, in order to eliminate the uncertainty of failure time of cladding, see Figure 4. Test results are published by Just (2009).

Strength-graded wood, class C24, was used for wall studs, produced by Stora Enso Imavere sawmill in
Estonia. All studs were cut from the same batch of raw material. Characteristic density of the studs was measured from 404 to $538 \mathrm{~kg} / \mathrm{m}^{3}$.

Stone wool (rock wool) is a mineral wool manufactured predominantly from molten naturally occurring igneous rocks (EN 13162). The maximum service temperature of stone wool is usually around $1000{ }^{\circ} \mathrm{C}$. Stone wool used in tests was produced in four different factories. Densities of stone wool insulations used in the test structures ranged from $28 \mathrm{~kg} / \mathrm{m}^{3}$ to $37 \mathrm{~kg} / \mathrm{m}^{3}$ (Table 3).

Heat-resistant glass wool (glass wool with high maximum service temperature) is a new innovative glass wool with high maximum service temperature. It is resistant to high temperatures. This is achieved by using a proprietary and patented glass compound. The material is manufactured using technology similar to that used for traditional glass wool. The difference lies in higher quality of the raw material and a higher temperature in the production process. The proprietary and patented glass compound adds very high temperature resistance. Insulation properties of the material at normal temperatures are similar to the traditional glass wool. Densities of heat-resistant glass wool insulations, used in test assemblies in this study, were $14 \mathrm{~kg} / \mathrm{m}^{3}$ and $21 \mathrm{~kg} / \mathrm{m}^{3}$ (Table 3). Identification of stud numbers of tested walls is presented in Fig. 5.
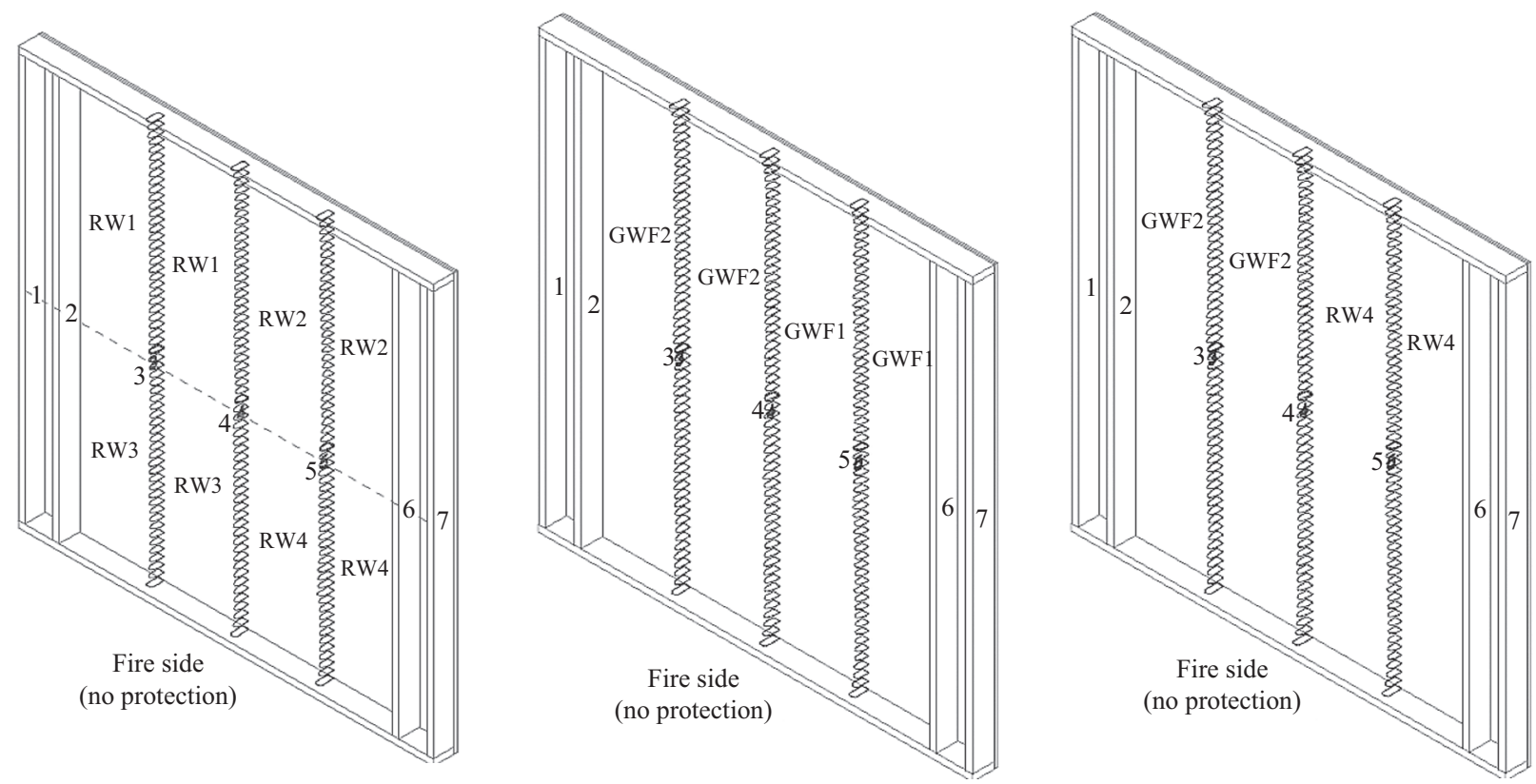

KEY: RW1 to RW4 - different stone wool products, GWF1 and GWF2 - different heat-resistant glass wool products

Fig. 4. Test assemblies 
Table 3. Densities of tested insulation materials

\begin{tabular}{|ccc|}
\hline Material & Densities, $\mathrm{kg} / \mathrm{m}^{3}$ & Average density, $\mathrm{kg} / \mathrm{m}^{3}$ \\
\hline $\begin{array}{c}\text { Heat-resistant } \\
\text { glass wool GWF2 }\end{array}$ & 20,5 to 21,1 & 21,0 \\
\hline $\begin{array}{c}\text { Heat-resistant } \\
\text { glass wool GWF1 }\end{array}$ & 13,8 to 14,7 & 14,3 \\
\hline Stone wool, RW4 & 29,0 to 30,0 & 29,4 \\
\hline Stone wool, RW3 & 36,2 to 37,1 & 36,6 \\
\hline Stone wool, RW2 & 28,9 & 28,9 \\
\hline Stone wool, RW1 & 27,9 to 30,5 & 29,4 \\
\hline
\end{tabular}

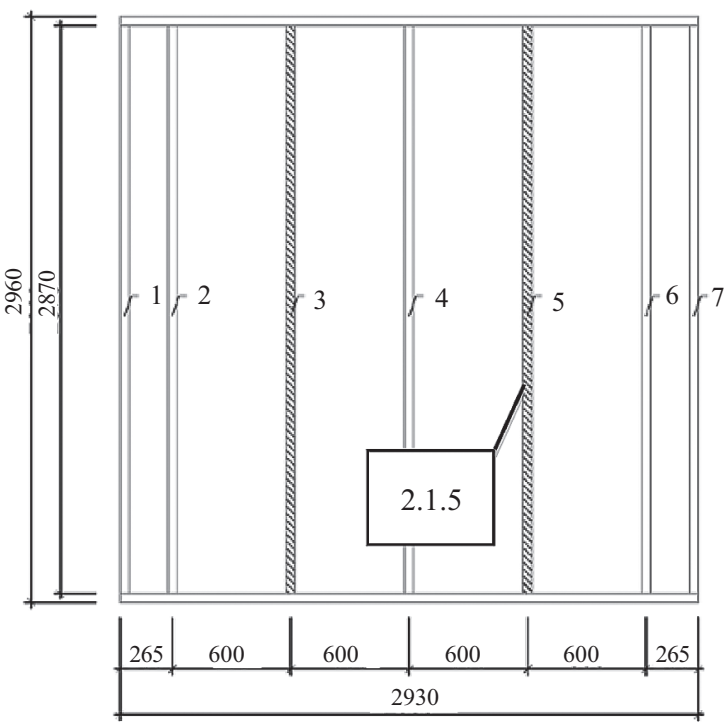

KEY: 3, 5- scanned studs (hatched)

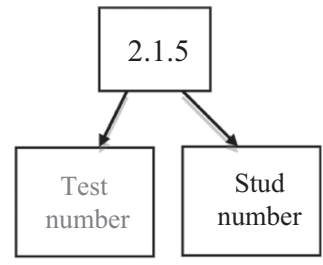

Fig. 5. Idendification of stud numbers of tested walls.

View from the fire side

\section{Analysis of charred cross-sections}

After the fire tests, the full lengths of the studs were recovered. The char layer was mechanically removed from the studs, which were the scanned and three dimensional models created. Cross-section properties and densities of the studs were measured for each $50 \mathrm{~mm}$ slice.

To create the three-dimensional models, the burnt studs were scanned by an optical three-dimensional ATOS (Advanced Topometric Sensor) II scanner at Tallinn University of Technology, Faculty of Mechanical Engineering, Department of Mechatronics (Fi- gure 6). Measurement reference points were created by attaching targets to the object: see Figure 7 . These targets define the object coordinate system in the particular object ranges. The single views were recorded with the sensor. The different views were transformed automatically into the object coordinate system of the ATOS II software using the reference targets. When

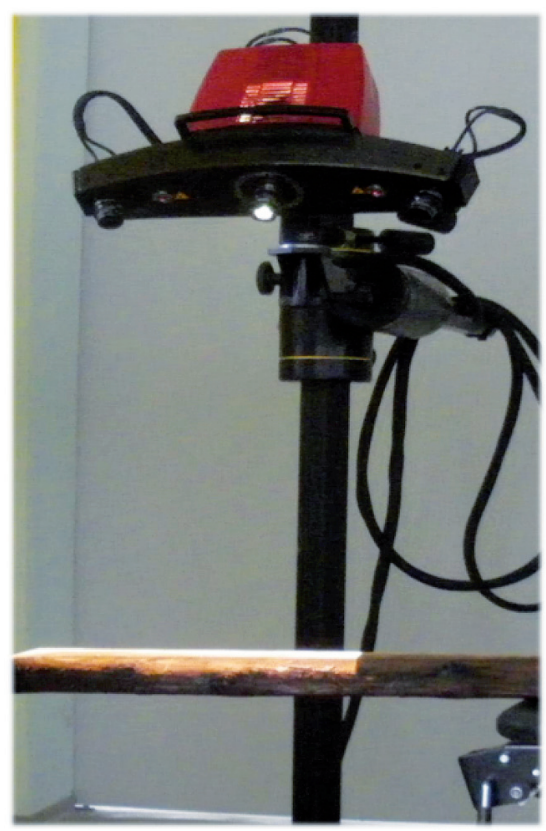

Fig. 6. Three dimensional ATOS II scanner

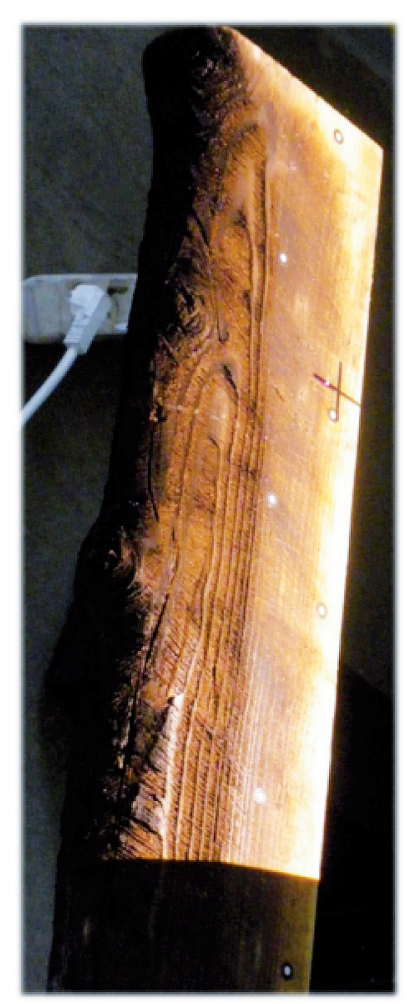

Fig. 7. Detail with reference targets 
recording the views, it is important that at least three reference targets are visible for both ATOS II cameras simultaneously. Their 3D coordinates were determined in the ATOS II sensor coordinate system and then transformed into the global coordinate system. The system checks for disturbances such as ambient vibrations and automatically repeats the measurement if necessary. The measured data were exported in computer-aided design programs for further three-dimensional analysis. A digitised three-dimensional model of one wall stud is shown in Figure 8.

Detailed section properties of all charred crosssections are given by report of Just et al. (2010).

\section{Measuring densities}

Densities were measured by an X-ray scanner, which was combined with an optical Goldeneye 706 vibration scanner at the Stora Enso Imavere sawmill in Estonia. The Goldeneye scanner is designed for linear board flow, and provides 'multi-sensorial' scanning that includes:

Laser scanning for geometric measurement;

4 -face colour camera scanning for external characteristics;

X-ray scanning for density measurement, knot identification and strength prediction.

The X-ray scanning resolution is around $0,8 \mathrm{~mm}$ across the board and $5 \mathrm{~mm}$ along the board at $450 \mathrm{~m} / \mathrm{min}$ feed rate (Gjudiceandrea 2005). Density was determined by weighing the mass of timber or by $\mathrm{X}$-ray scanning with moisture determination. Goldeneye uses X-radiation to determine knots and density of a board. The radiation is partially absorbed, depending on the thickness, moisture content and density of the board, producing a grey-scale image suitable for image processing. Since the density of knots is approximately twice as high as the density of the surrounding clear wood, knots can be detected accurately in terms of size and position. The non-contact method also allows high-speed operation - at $1600 \mathrm{scans} / \mathrm{sec}$ combined with an infeed of $400 \mathrm{~m} / \mathrm{min}$, a resolution of $4 \mathrm{~mm}$ is achieved in the length direction. The X-ray scanner produces stable knottiness and density signals, with highly repeatable results (Gjudiceandrea 2005).

Optical vibration measurement (OVM) to determine the characteristic frequency is performed by hitting the front side of the boards during cross-feeding by a special ball-shaped impact device. The mechanical excitation causes the board to vibrate. For optimum performance, the front side of the board has to be plane, so a chipping tool is typically used to prepare the surface of the board. A laser vibrometer is used to detect the characteristic vibrations of the board. The laser vibrometer produces a very stable signal, yielding highly repeatable results, unless the board is turned or flipped. The instrument is housed in a protective casting with small footprint.

As mentioned, the best performance in predicting strength and stiffness is achieved by combining different and independent characteristic properties. The best result is achieved by combining knottiness, density and characteristic frequency. This is achieved by connecting the X-ray scanner and vibration measurement in the same grading process. In a typical instal-

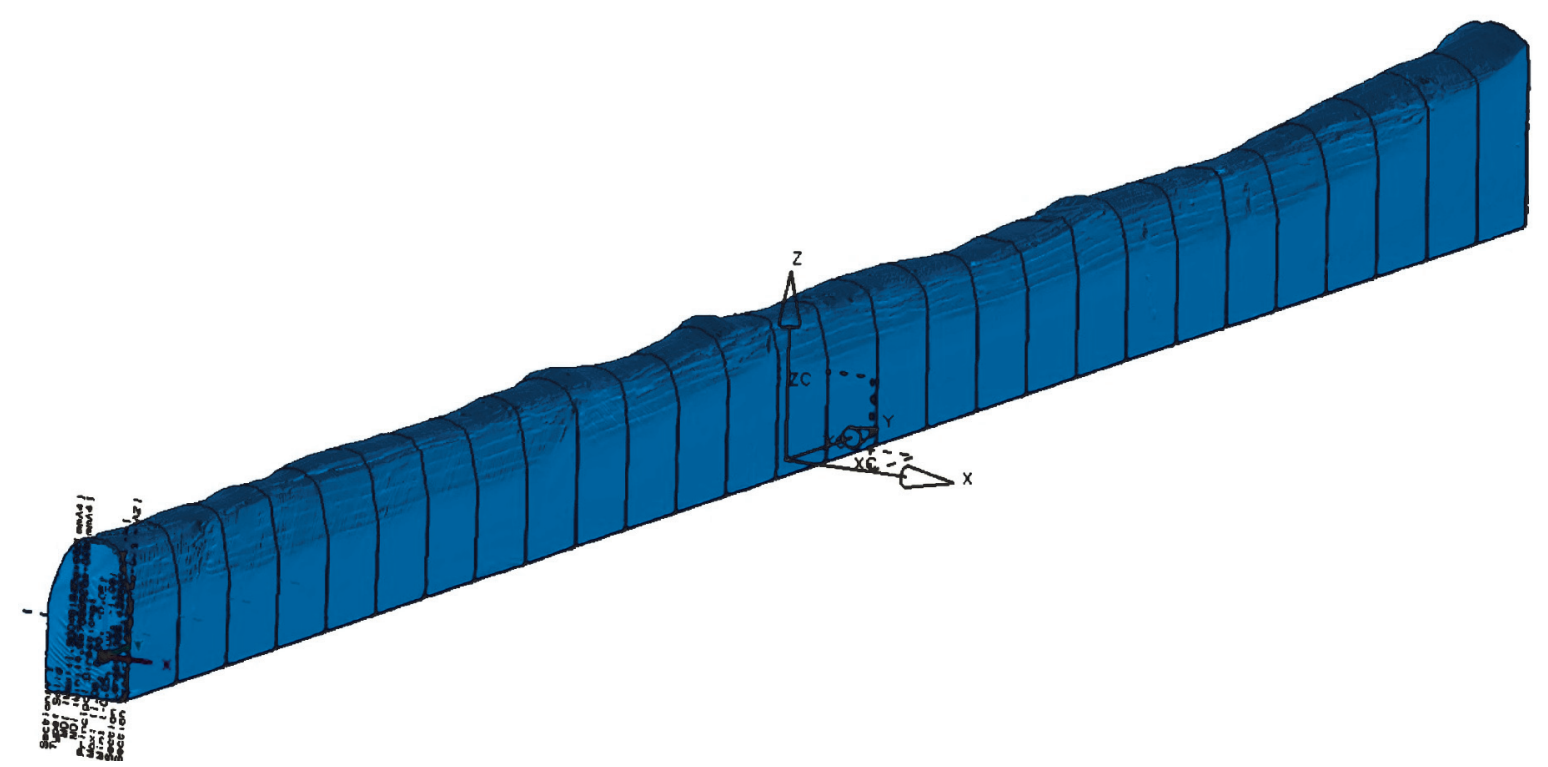

Fig. 8. Digitized three dimensional model 
lation, vibration measurement is performed in crossfeeding before the planer intake. The X-ray scanner is positioned immediately after the planer. The information from the vibrometer is stored until the X-ray scanner analyses the board, at which point the results from the two data sources are linked and the vibration information is used with the other indicating properties to predict strength and stiffness.

\section{Variability of charring depth and density}

Six studs and six different heat-resistant insulation materials were investigated. Only those without cladding on the fire-exposed side were studied. Minimum and maximum values of densities were found and according to value of density, notional charring was taken into account. Two different examples of section modulus of residual cross-sections and respective densities in the full stud length are shown in Figures 9 and 10. Figure 9 represents a stud with stone wool insulation (stud number 2.2.5), and Figure 10 represents a stud insulated with heat-resistant glass wool (stud number 2.4.3). Variability of section modulus of charred cross-sections and variability of density is remarkable. The differences in densities of wood within one stud have been measured as up to $41 \%$. The peaks in $\mathrm{Fi}$ gures 9 and 10 probably correspond to the positions of knots. The knots have higher densities than has the surrounding wood. Charring depth calculated according to EN 1995-1-2 is shown with the smooth line and charring depth using new value for cross-section factor $\left(k_{\mathrm{s}}=1,6\right)$ is shown with the dashed line in Figures 9 and 10 .

The difference in charring rate as a result of changing one property or factor varies also, as can be seen in Table 4. Charring rate varied between $2,5 \%$ and $11,2 \%$ in the case of stone wool, and 3,2\% and 5,0\% in the case of heat-resistant glass wool within one stud. Higher charring rates were noticed for lower densities of timber and for lower densities of insulation.

Horizontal joints of insulation are shown in Figure 11. The positions of joints are shown in Figures 9 and 10 by a dotted line. Although the heat-resistant glass wool exhibits thermal expansion at joints, the greater charring depth is measured at the positions of joints in the insulation. This has been studied by Just et al. (2010), where it was found that only the outer part of joints of heat-resistant glass wool open up on the fire-exposed side, and stay closed on the unexposed side. Timber studs insulated by stone wool did not show greater charring depth at insulation joint positi- ons, because stone wool normally shrinks over the entire thickness.

The studs investigated in the study were all produced in the same batch. Moisture content was 11 to $12 \%$ for all of the studs. The trials were performed without cladding on the fire-exposed side, in order to eliminate the uncertainty element introduced by cladding failure. That makes the results comparable and the difference in measured charring rates is mostly caused by density and size effect of cross-section. The size effect of the same studs was researched by Just et al (2010) by the author of this paper, and the recommended increased value for size factor has been used in this study. The influence not considered in real charring rate is most probably the density of wood.

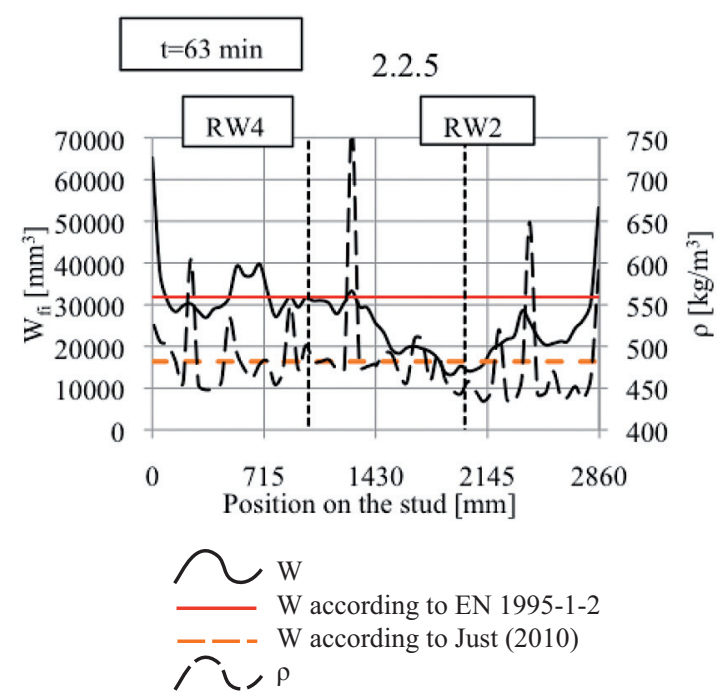

Fig. 9. Variability of section modulus of charred cross-sections and density for stud 2.2.5

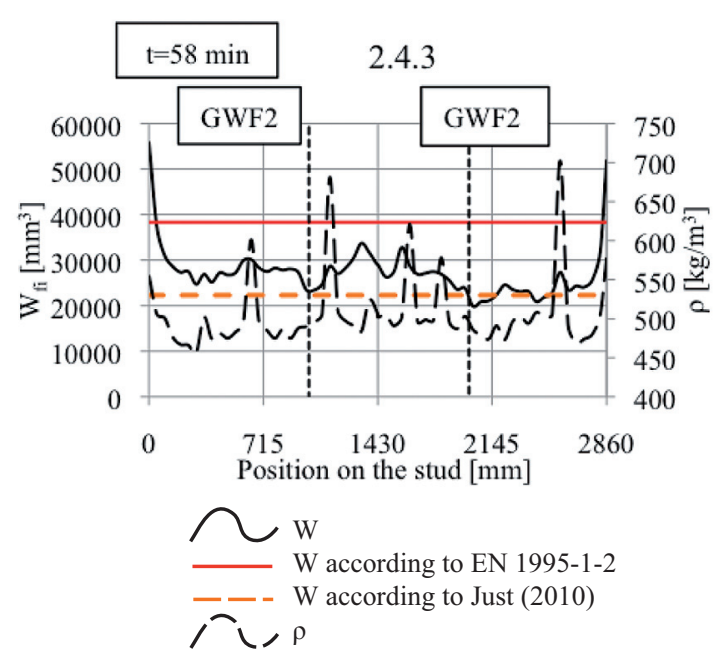

Fig. 10. Variability of section modulus of charred cross-sections and density for stud 2.4.3 
Table 4. Density of timber and insulation affecting charring rate of Tests 2.2 to 2.4 , see Figure 5 for locations

\begin{tabular}{|c|c|c|c|c|c|c|}
\hline \multirow{2}{*}{ Stud no. } & \multicolumn{2}{|c|}{ Insulation } & \multicolumn{4}{c|}{ Timber } \\
\cline { 2 - 7 } & Type & Density $\left[\mathrm{kg} / \mathrm{m}^{3}\right]$ & Density $\left[\mathrm{kg} / \mathrm{m}^{3}\right]$ & $\begin{array}{c}\text { Difference in } \\
\text { density }[\%]\end{array}$ & $\mathrm{d}_{\text {char, } \mathrm{n}}[\mathrm{mm}]$ & $\begin{array}{c}\text { Difference in char- } \\
\text { ring rate }[\%]\end{array}$ \\
\hline 2.2 .3 & RW1 & 29 & 467 to 599 & 22.0 & 78.6 to 80.6 & 2.5 \\
\hline 2.2 .3 & RW3 & 37 & 501 to 704 & 28.8 & 74.0 to 83.3 & 11.2 \\
\hline 2.2 .5 & RW2 & 29 & 434 to 649 & 33,1 & 86.4 to 90.2 & 4.2 \\
\hline 2.2 .5 & RW4 & 29 & 448 to 762 & 41.2 & 78,4 to 85.1 & 7.9 \\
\hline 2.3 .3 & GWF2 & 21 & 512 to 723 & 29.2 & 77.8 to 81.9 & 5.0 \\
\hline 2.3 .5 & GWF1 & 14 & 492 to 658 & 25.2 & 87.4 to 90.3 & 3.2 \\
\hline 2.4 .3 & GWF2 & 21 & 456 to 702 & 35.0 & 84.7 to 87.6 & 3.3 \\
\hline 2.4 .5 & RW4 & 29 & 524 to 768 & 31.8 & 70.5 to 74.8 & 5.8 \\
\hline
\end{tabular}

Test 2.2

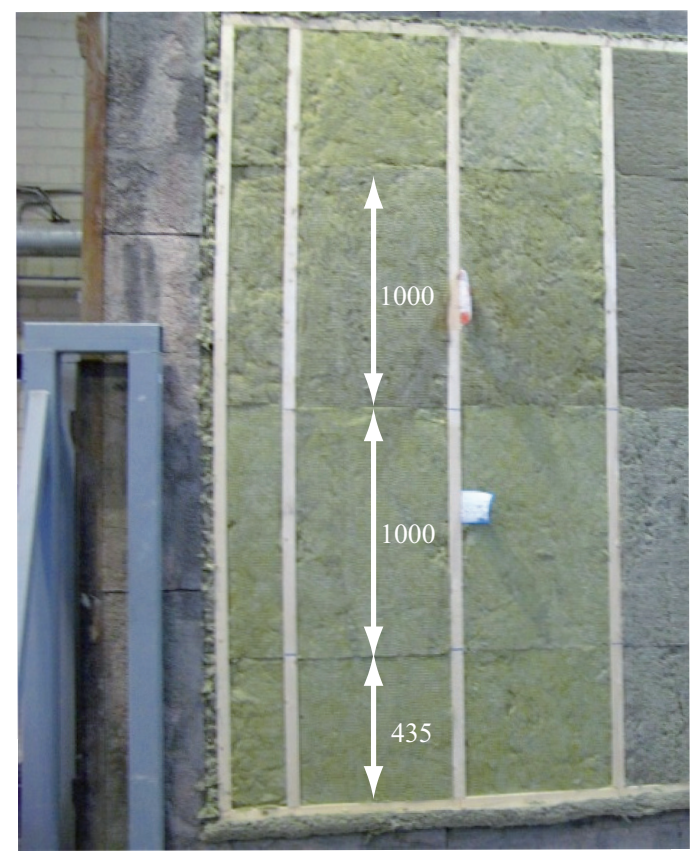

Test 2.3 and Test 2.4

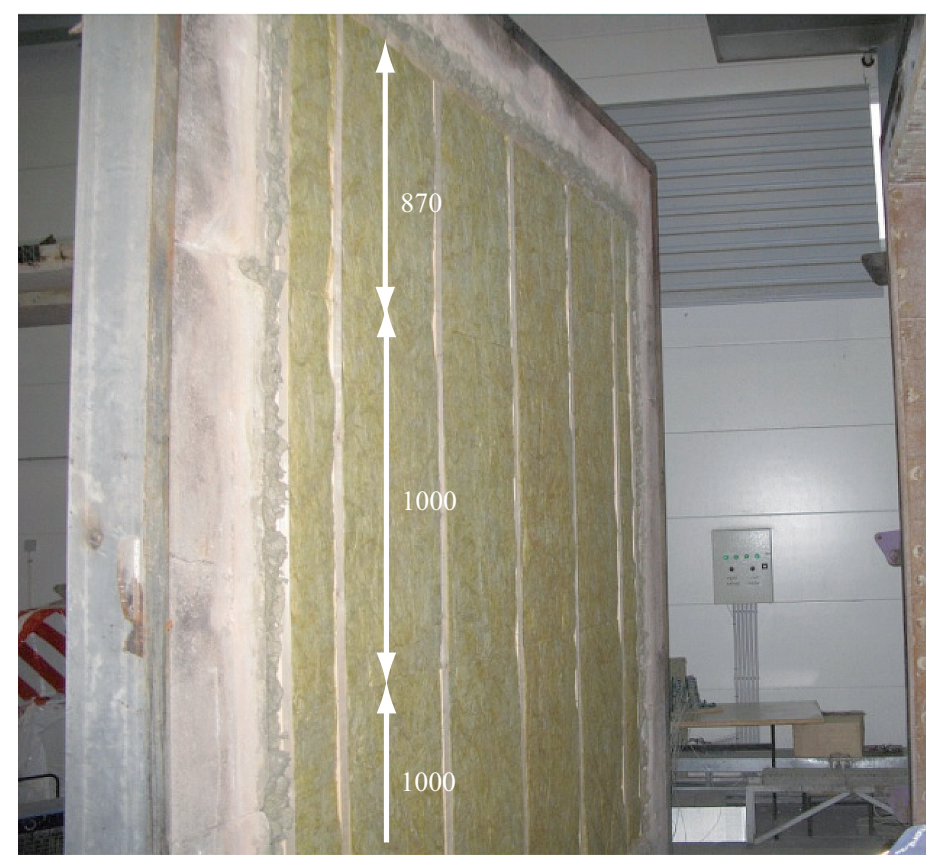

Fig. 11. Test walls before the fire tests. Locations of joints of insulation

\section{Charring related to density}

The relationship between the charring rate of insulated members and the density of wood is shown in Figures 12 and 13. Each point represents a $50 \mathrm{~mm}$ slice of scanned stud. Figure 12 shows the sections with stone wool insulation, and Figure 13 shows the sections with heat-resistant glass wool insulation.

A linear trend line is used because of better correlation with test data. The effect of density on charring rate is described as follows:

Charring rate for timber frame members insulated by stone wool:

$\beta=1,44-\rho / 1428$.
Charring rate for timber frame members insulated by heat-resistant glass wool:

$\beta=1,32-\rho / 833$.

The charring rates expressed in Equations (7) and (8) are determined mainly by the size effect and effect of density, see Equation (9). To express the influence of density on the charring rate, the density coefficient $k_{\text {dens }}$ is introduced just for this study. Cross-section factor $k_{\mathrm{s}}$ in Equation (9) is as given by new results by Just (2010). In the present stage of studies, the values of densities obtained from tests do not match the characteristic densities of strength classes according to EN 338. 


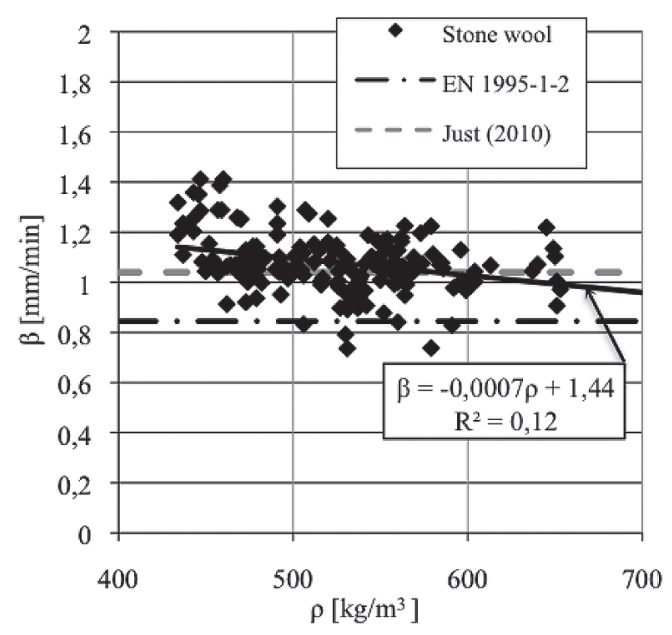

Fig. 12. Relationship between density and charring rate of timber members insulated by stone wool

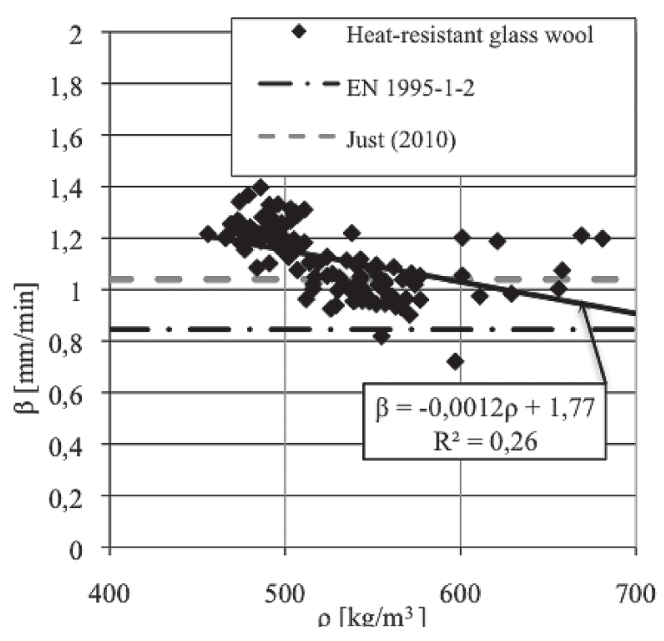

Fig. 13. Relationship between density and charring rate of timber members insulated by heat-resistant glass wool

$\beta=k_{\text {dens }} k_{\mathrm{s}} \beta_{0}$,

where $k_{\mathrm{s}}=1,6 \beta_{0}=0,65 \mathrm{~mm} / \mathrm{min}$.

According to EN 1995-1-2 there is no difference of charring rate for densities greater than $290 \mathrm{~kg} / \mathrm{m}^{3}$. The following coefficient for charring rate related to density of wood is derived from Equations (7), (8) and (9), based on the trend line of the results of this study and a density of $290 \mathrm{~kg} / \mathrm{m}^{3}$ :

For stone wool:

$k_{\text {dens }}=1,14-\frac{\rho}{2230}$,

for heat-resistant glass wool:

$k_{\text {dens }}=1,20-\frac{\rho}{1300}$,

where $\rho$ is the density of wood in $\mathrm{kg} / \mathrm{m}^{3}$.

The results of this study showed that charring of timber members insulated by heat-resistant insulation could be faster in reality than the design model in EN 1995-1-2. This is reported by Just (2010). This paper has used the increased charring rate with the new proposed value for cross-section factor $k_{s}$.

The difference in density of wood within a single wall stud has been measured as up to $41 \%$ in many cases. The charring rate can also have a wide variation over the full length of a single timber wall stud. In this study, the effect of the density of the wood has been assumed to influence the charring rate by up to $20 \%$.

\section{Conclusions}

1. A quite remarkable variation of wood density, up to $41 \%$ within a single wall stud, was registered in this study.

2. Charring rate is not uniform over the full length of a single timber wall stud, but can vary by up to $20 \%$. This corresponds to the variation of density of the wood.

3. The charring rate of wood is dependent on the insulation materials surrounding the timber member on the wide sides. Tests showed different charring rates for studs insulated with heat-resistant glass wool or with stone wool when using the same test conditions.

4. Joints between insulation batts often increase charring rates when using heat-resistant glass wool.

5. A factor relating charring rate to the density of wood in timber frame wall assemblies is given as a result of this study, but it is based on a small number of tests and must be further investigated.

\section{References}

AS 1720.4. Timber structures: Fire resistance of structural timber members. Australian standard.

Babrauskas, V. 2005. Charring rate of wood as a tool for fire investigations, Fire Safety Journal 40: 528-554. Elsevier.

Cachim, P.; Franssen, J-M. 2010. Assessment of Eurocode 5 charring rate calculation methods, Fire Technology 46: 169181. Springer Science \& Business Media.

EN 338:2008. Structural timber - Strength classes. European Standard, CEN, European Committee for Standardization, Brussels, 2008.

EN 1995-1-2:2004 Eurocode 5: Design of Timber Structures. Part 1-2: General Rules. Structural Fire Design. European Committee for Standardization, Brussels, 2004.

EN 13162:2008. Thermal insulation products for buildings Factory-made mineral wool products - Specification. European Standard. European Committee for Standardization, Brussels.

Friquin, K. L. 2010. Charring Rates of Heavy Timber Structures for Fire Safety Design. PhD thesis. NTNU. Trondheim. 
Gjudiceandrea, F. 2005. Stress Grading Lumber by a Combination of Vibration Stress Waves and X-ray Scanning. Italy.

Just, A. 2009. Full-scale wall tests of timber frame assemblies. Test report. Tallinn: Tallinn University of Technology.

Just, A.; Schmid, J.; König, J. 2010. The effect of insulation on charring of timber frame members. SP Report 2010:30. SP Trätek, Stockholm.

König, J.; Walleij, L. 2000. Timber frame assemblies exposed to standard and parametric fires. Part 2: A Design model for standard fire exposure. Trätek, Stockholm.

Schaffer, E. L. 1967. Charring rate of selected woods - transverse to grain, FPL Research Paper 69. Forest Products Laboratory: Madison, Wisconsin, USA.

Schmid, J.; König, J. 2010. Model-scale fire tests of Isover Ultimate - step 1.2 - Load Bearing Capacity. SP Report 2010:26. SP Trätek, Stockholm.
Syme, D. 1994. Verification of charring equations for Australian timbers based on full-scale fire resistance tests, in Proceedings of Pacific Timber Engineering Conference, vol 1: 619-623. Australia, Queensland University of Technology.

Tera, T. 2010. Charring of timber studs insulated by heat-resistant glass wool and rock wool. Master thesis at Tallinn University of Technology. Tallinn.

Thali, M. J.; Braun, M.; Dirnhofer, R. 2003. Optical 3D surface digitizing in forensic medicine: 3D documentation of skin and bone injuries, Forensic Science International, Elsevier.

White, R. H. 1988. Charring rates of different wood species. $\mathrm{PhD}$, University of Wisconsin-Madison. Madison, USA.

\section{MEDINIŲ KARKASINIŲ SIENŲ STATRAMSČIŲ APANGLĖJIMO GYLIO KITIMAS}

\section{A. Just, T. Tera}

Santrauka. Straipsnyje analizuojama skirtingo medienos tankio, apsaugoto ugniai atsparia mineraline vata, ittaka apanglèjimo gyliui. Ypatingas dèmesys atkreiptas ị skirtingą apanglèjimo gylị per visą statramsčio ilgị. Atlikus realių matmenų medinių karkasinių sienų ugnies poveikio eksperimentinị tyrimą, statramsčiai liko išsaugoti per visą ilgị. Nuo apanglëjusių statramsčių anglis mechaniniu būdu buvo nuvalyta, statramsčiai nuskenuoti trimačiu skeneriu, rentgenu buvo išmatuotas statramsčių tankis. Apanglëjimo gylis per visą statramsčio ilgị buvo skirtingas. Tikètina, kad tai lèmè skirtingas medienos tankis. Todèl skirtingo medienos tankio vertinimas, tobulinant EN 1995-1-2 reglamentuojamą medienos apanglèjimo skaičiavimo modelį, galètų suteikti pranašumų didesnio tankio elementams.

Reikšminiai žodžiai: apanglèjimo greitis, medinio karkaso surinkimas, apanglëjimo gylis, tankio ịtaka.

Alar JUST. PhD. Faculty of Civil Engineering. Tallinn University of Technology. Researcher in SP Trätek. Research interests: glulam, timber bridges, fire safety of timber structures.

Tarmo TERA. MSc. Faculty of Civil Engineering. Tallinn University of Technology. Currently finished his master studies. Works as a project manager in building enterprise Astlanda. 